\title{
PESSOAL
}

\section{Da Condição Jurídica dos Cônsules}

\author{
Geraldo Eulálio do Nascimento \\ e Silva \\ (Professor do Instituto de Altos Estudos In- \\ ternacionais da Universidade de Paris e do \\ Instituto Rio Branco. Secretário da Comissão \\ Nacional de Codificação do Direito Inter- \\ nacional)
}

\section{CONCEITO DE CÔNSUL}

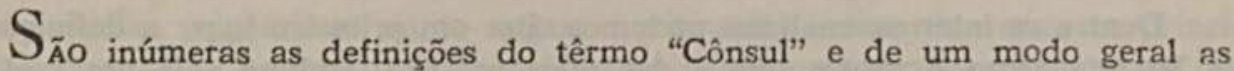
mesmas se limitam a uma enumeração de suas atribuições. E de mister lembrar que a expressão varia no tempo e no espaço: o Cônsul de hoje possui atribuições bem mais complexas do que o de um século atrás, e as funções consulares variam de país para país. Aliás, na organização ccnsular de um mesmo país, na qual todos os funcionários se acham vinculados a um mesmo estatuto, suas atribuições oscilarão de pôsto para pôsto, pois nem tôdas as repartições consulares têm por finalidade a proteção đo comércio e da navegação e o auxílio de nacionais; algumas são criadas com finalidades políticas, outras terão caráter mais cultural. Também, é necessário, de início, saber se devemos ou não incluir sob a designação de cônsul os chamados cônsules honorários. Alguns autores esclarecidos vêm propugnando desde há muito pela adoção do Regulamento adotado pelo Instituto de Direito Internacional na sua sessão de 1896 (Veneza), no sentido de que o título de cônsul só deve pertencer aos cônsules missi, isto é, aos funcionários nacionais do estado que os ncmeia e que não exercem outra função que a consular; ao passo que aos chamados consules electi se deveria dar o título de agente consular. (1)

Infelizmente a questão é de difícil solução, pois os países carecedores de recursos financeiros e que não podem manter um corpo consular organizado hieràrquicamente, mas que são forçados a recorrer aos negociantes radicados nas principais cidades e portos comerciais, não se conformarão em acolher uma norma que irá despir os seus representantes da situação social e jurídica de que gozavam, mesmo sabendo que não se justifica a equiparação entre os cônsules de carreira e os agentes consulares.

(1) Annuaire de l'Institut de Droit Internacional, vol. III (edição de 1928) p. 1077. 
Enquanto êste ponto não fôr solucionado satisfatória e unânimemente, perdurarão as polêmicas sôbre a condição jurídica dos cônsules e a precedência entre êles.

Seja como fôr, alguns países já reservam o título de cônsul para cs funcionários de sua nacionalidade, que percebem vencimentos e são proibidos de exercer outra função remunerada. E pena que o Brasil, cuja organização diplomático-consular é ímpar na América latina, não adote a mesma nomenclatura. Não basta, contudo, adctar as citadas denominações para o corpo consular nacional, é necessário ainda condicionar a concessão do exequatur aos cônsules estrangeiros a esta orientação.

Feita esta introdução, é lícito dar-se uma definição ao têrmo, a qual como tôda definição terá o inconveniente de limitar a instituição em estudo. Conforme foi dito, as definições existentes são de caráter exemplificativo, pois giram em tôrno de uma enumeração de funções, sejam elas de autoria de etimologistas, internacionalistas, magistrados ou legisladores. Assim CÂNDIDo DE FiguEIREDo ensina "agente de uma nação, encarregado, em país estrangeiro, de proteger os súditos dessa nação, fomentar o comércio, etc." (2)

Dentre os internacionalistas podemos citar em primeiro lugar a definição de Hildebrando Accioly, que é das mais precisas, embora seja um tanto quanto extensa: "os cônsules são funcionários administrativos ou agentes oficiais, sem caráter diplomático ou representativo, que um Estado nomeia para servirem em cidades ou portos de outros Estados, com a missão de velar pelos seus interêsses comerciais, prestar assistência e proteção aos seus nacionais, legalizar dccumentos pertencentes a êstes ou destinados a produzir efeitos no seu país, exercer a polícia da navegação com os portos nacionais, fornecer informações de natureza econômica e comercial sôbre o país ou distrito onde sirvam". (3)

Igualmente extenso e mais ou menos nos mesmos moldes é o conceito dado por P. FAUCHILle: "os cônsules são os agentes oficiais que um Estado estabelece nas cidades cu nos portos de país estrangeiro, com a missão de cuidar de seus interêsses comerciais, prestar assistência e dar prcteção aos seus nacionais, comerciantes ou viajantes, desempenhar com relação a êles funções administrativas (ou judiciárias), exercer a polícia da marinha mercante, velar pela execução dos tratados de comércio e navegação, fornecer dados sôbre as produções agrícolas e industriais e sôbre o movimento dos países estrangeiros". (4)

Poderíamos multiplicar as definições dos autores de obras gerais sôbre o direito das gentes, mas basta dizer que com algumas variações de fundo nu

(2) Novo Dicionário da Língua Portuguêsa, $4 .^{\mathrm{a}}$ ed., Lisboa, vol. $1 .^{\circ}$, p. 514.

(3) Tratado de Direito Internacional Público, vol. II, Rio de Janeiro, 1956, n. 0801, p. 513 . p. 109 .

(4) Traite de Droit International Public, vol. I, parte $3 .^{a}$, Paris, 1926, n. $0^{\circ} 733$, 
forma, de síntese ou análise, seguem orientação parecida às de BLUNTSCHLI, (5) Bustamante y Sirven, (6) e Luiz de Faro Junior. (7)

Os autores de trabalhos específicos sôbre o direito consular adotam definições parecidas conforme poderemos constatar pelo exame de algumas.

IRIZARRY Y PUENTE : "No sentido genérico, um cônsul é um funcionário enviado por um Govêrno para residir num país estrangeiro, e admitido pelo Govêrno dêsse país, múltiplas finalidades administrativas, mas antes de tudo para representar, estimular e proteger os seus interêsses nas relações econômicas, marítimas e comerciais, bem como as pessoas e os interêsses de seus cidadäos ou súditos". (8)

João Penteado Erskine Stevenson: "cônsul é o agente ou delegado que uma nação mantém em país estrangeiro, sobretudo nas cidades comerciais ou portos, para defender seus interêsses mercantis ou marítimos, com funções administrativas, judiciárias e acidentalmente políticas, e garantir os direitos e privilégios dos seus súditos".

MARCELO ARDUINo, contudo, não aceita as definições vazadas nos moldes das citadas, julgando-as muito vagas, e criticando o fato de versarem principalmente sôbre as atribuições consulares e não conterem uma conceitucsa determinação da essência jurídica da função consular em si. (10)

As definições que se nos deparam em algumas decisões jurídicas são fracas, pois a finalidade das mesmas é, geralmente, justificar a competência dos tribunais locais e não dar uma noção científica da instituição. A Primeira Câmara da Côrte de Apelação do Distrito Federal, em acórdão de 14 de janeiro de 1907, relativo a uma ação de imissão de posse, na qual era agravante - Cônsul Geral da Suiça, teve ensejo de declarar que "os cônsules não são representantes do Estado, são agentes protetores dos interêsses dos cidadãcs da Nação que servem dentro do território estrangeiro onde exercem jurisdiçäo". (11)

Os regulamentos consularem freqüentemente contêm definiçōes do caráter dos respectivos funcicnários.

$\mathrm{O}$ primeiro texto brasileiro sôbre a matéria - o decreto $\mathrm{n} .^{\circ} 520$, de 11 de junho de 1847 , que mandava executar o novo regulamento consular, dispunha no artigo primeiro: "Aos cônsules incumbe, nos seus distritos e lugares de residência, promcver o comércio e navegação, bem como proteger as pessoas e interêsses dos súditos brasileiros." O dispositivo em questão foi reproduzido no Regulamento de 1872 e figurou na primeira Consolidação organizada

(5) Le Droit International Codifié, 5. a ed., Paris, 1895, art. 244, p. 160.

(6) Droit International Public, vol. I, Paris, 1934, n. ${ }^{\circ} 301$, p. 403

(7) Manual de Direito Internacional Público, 2.a ed., Rio de Janeiro 1956, n. ${ }^{\circ} 720$. p. 366 .

(8) Traité sur les Fonctions Internationales des Convuls, Paris, 1937 p. 9.

(9) Curso de Direito Consular, São Paulo, 1939, n. ${ }^{\circ} 64$, p. 44.

(10) Consoli, Consolati e Diritto Consolari, Milán, 1908, p. 27.

(11) Revista de Direito (Bento de Faria), vol. IV (1907), p. 439. 
na República, em 1899, com a substituição da palavra "súditos" por "cidadãos".

O Decreto-lei n. ${ }^{\circ} 9.121$, de 3 de abril de 1946 , que trata da organização do Ministério das Relações Exteriores, não definiu a expressão cônsul, mas sim a de repartição consular.

Finalizando é lícito lembrar que dadas as afinidades entre 0 serviço consular e o diplomático, não se pode ainda dar uma definição de acôrdo com a indicação de M. ARDuino: pode-se, isto sim, tentar combinar na mesma a determinação jurídica da função consular (que muito se aproxima à diplomática) e manter uma enumeração de atribuições a fim de caracterizar melhor o cônsul e dizer que é o funcionário público nomeado pcr um Estado para o representar em pôrto ou cidade de outro, com a incumbência de, evitando se imiscuir nas atribuições da respectiva missão diplomática, velar por todos cs seus interêsses, quer sejam êles de natureza comercial, econômica, cultural, financeira, política ou social e, principalmente, exercer a polícia da navegaçăo e velar pela pessoa e os bens de seus nacionais. (12)

\section{HISTÓRICO DA INSTITUIÇÃo CONSULAR}

No estudo da evolução histórica da instituição consular é lícito destacar quatro fases mais ou menos distintas. A primeira abrange as práticas adotadas na antiguidade e que têm certa analogia $\mathrm{ccm}$ a instituição; a segunda começa pouco antes da primeira cruzada e termina com as embaixadas permanentes; a terceira, de decadência da instituição, chega ao século XIX; a quarta surge em meados do século XIX, e nela a instituição consular readquire seu antigo prestígio.

Conforme lembra Clovis Bevilaqua, "as associações políticas primitivas, sob 0 influxo dos sentimentos guerreiros e religiosos, olhavam para o estrangeiro como para um inimigo que estivesse constantemente ameaçando a sua existência e a sua religião. O estrangeiro não colaborava para o bem estar da comunidade, falava outra língua, adorava outros deuses, adotava outros costumes, não podia merecer benevolência". (13) Na India era êle colocado abaixo do pátria; no Egito, ao natural do país repugnava tocar num instrumento utilizado por um grego; na Grécia e em Roma um estrangeiro não podia desposar u.na nacional, possuir imóveis ou firmar contrato com um cidadão".

A esta primeira reação de hostilidade veio se juntar outra, mais favoravel ao alienígena, geralmente um comerciante, cuja presença vinha trazer benefícios à comunidade. Passaram a ser tolerados; mas como sobrevivência da antiga xenofobia, continuavam à margem da sociedade e de suas leis. Nessas condições, era mister escolher alguém que os julgasse, dai surgindo várias soluções.

(12) G.E. Do Nascimento e Silva: Manual de Derecho Consular (Rosario 1952). p. 72 .

(13) Principios Elementares de Direito Internacional Privado, $4 .^{\mathrm{a}}$ ed,, Rio de Janeiro, 1944, s pp. 153 e 154 . 
$\mathrm{Na}$ Grécia, havia os proxenos, que muito tinham em comum com os atuais cônsules honorários, e cuja origem remonta ao VI século a.C. Os proxenos eram indivíduos designados oficialmente por uma cidade grega para em outra velar pelcs seus interêsses e proteger os seus cidadãos. Eram nacionais da cidade em que exerciam as suas funções e não da representada. Inicialmente, a proxenia era uma proteção espontânea, mas com o desenrolar do tempo, dados os bons resultados obtidos, se oficializou, passando a ser um cargo cobiçado, dadas as vantagens e honras que trazia.

E interessante lembrar que os atuais cônsules gregos são igualmente chamados proxenos.

Dada a vinculação existente entre a instituição consular e o comércio, é fácil compreender que aquela não tivesse se desenvolvido entre os romanos, avessos à mercancia.

Tinham, ccntudo, certa semelhança com os proxenos os "Patronos" ou "protetores", nomeados geralmente pelo Senado para proteger os interêsses das cidades conquistadas pelos exercícios de Roma; se bem que, por vêzes, a escolha fosse feita pela própria cidade.

Em Roma, temos ainda a figura do "praetor peregrinus", incumbido de solucionar as pendências surgidas entre os forasteiros ou entre êles e romanos, de acôrdo com os preceitos do jus gentium.

Se bem que o têrmo cônsul seja de origem latina, constata-se que em Roma os cônsules exerciam funções bem distintas dos cônsules da atualidade. Era o título dado, na Roma antiga, depois da expulsão dos reis, aos magistrados incumbidos de velar pelos supremos interêsses do Estado. Com o nesmo sentido surgiria na França com a queda da ditadura em fins do século XVIII.

Contudo, só com as cruzadas é que a prática de nomear cônsules em cidades e portos de comércio se consolida, não mais sofrendo ela solução de continuidade.

Não há dúvida de que as Cruzadas tiveram uma influência preponderante, ao ponto de inúmeros autores afirmarem que, a rigor, devemos procurar a origem da instituição consular no tempo das Cruzadas. (14) $\mathrm{Ccm}$ efeito, a fim de garantir a manutenção das tropas e peregrinos, os comerciantes de Veneza, Gênova e Pisa iam estabelecendo feitorias, onde os mesmos pudessem conseguir tudo de que necessitavam. A êstes comerciantes as Cruzadas cutorgavam inúmeros privilégios e quando de sua partida, os príncipes maometanos, reconhecendo as vantagens de sua permanência, permitiram que continuassem a usufruir dos mesmos. Assim, os comerciantes formavam uma coletividade não sujeita aos tribunais locais, mas $\operatorname{sim}$ a um magistrado de sua

(14) A. Heyking, Les Principes et la Pratique des Services Consulaires, (Paris, 1928) p. 20; A. RECHID, L'Islan et le Droit des Gens, em Recueil des Cours, tomo 60 (1937-II), p. 423; C. Calvo, Le Droit International, tomo III, (Paris - 1888), \& 1368, p. 215 . 
escolha, a quem incumbia igualmente a proteção dos membros da comunidade.

A circunstância de imperar o princípio da personalidade das leis entre os europeus e o fato do Corão só se aplicar aos muçulmanos veio permitir que os magistrados-cônsules desempenhassem, sem atrito, as suas funções judiciárias. Seja como fôr, a fim de evitar possivieis dificuldades, foram firmados entre os príncipes da Cristandade e os de Islam capitulaçōes tendentes a regulamentar as situações supervenientes.

Dentro em breve, o exemplo dos mercadores italiancs era imitados pelos de Barcelona e Marselha. A instituição foi sendo acolhida peles demais pevos, chegando ao Báltico.

Nessa segunda fase da instituição, a que P. FAUCHILle dá a denominação de "período municipal", (15) vemos que o soberano não influia na ủesignação do cônsul, era êle eleito pelos comerciantes e navegantes de determinada praça marítima, e assim, não tinha relações oficiais com o Estado de que era súdito.

No fim do "período municipal", eram várias as funções consulares e, de acôrdo com a terminologia moderna, eram elas judiciárias, diplomáticas e consulares pròpriamente ditas (prcteção da navegação e da pessoa e bens de seus nacionais).

A formação dos grandes Estados provocou profundas mudanças na instituição eonsular, que entrou num período de franca decadência.

Em primeiro lugar, o cônsul deixou de ser uma autoridade escolhida por uma comunidade: passou a ser nomeado por um soberano, adquirindo caráter público. Esta circunstância ligada ao abandono do sistema da personalidade das leis pelo da territorialidade, que vinha sujeitar todos os habitantes à justiça do país, independentemente de sua nacionalidade ou domicílio, acarretou a perda da atribuição principal dos cônsules: o de jurisdição, a não ser ncs países não-cristãos.

Com a formação dos grandes Estados surgem as Embaixadas permanentes, que depois do Tratado de Westfália se generalizaram. Com o aparecimento das mesmas, perderam os cônsules as suas funções diplomáticas e representativas, sem esquecer que ficaram num segundo plano em relação aos embaixadores.

Assim, aos cônsules sobravam poucas funções: velar pelos interêsses de seus nacionais c da navegação do país que os nomeou; o que pouco significava, iá que o comércio marítimo atravessava uma fase de pcuco movimento e raros eram aquêles que se aventuravam além das fronteiras de seu país.

Como passaram a ser funcionários de outros Estados, os poderes públicos condicionavam o exercício das funções consulares a uma autorização expressa chamada nos países europeus de exequatur e nos da Ásia Menor e do Norte da Africa de barat.

(15) Op. cit., n. ${ }^{\circ} 738$, p. 113. 
A função consular passou a ser meramente honorífica e quase sempre a escolha iria recair num comerciante local, nacional do país, para o qual a função consular seria secundária e que não pensaria duas vêzes na dignidade da nação por êles representada antes de cometer um crime ou recusar-se a pagar um credor.

Esse período dos cônsules honorários coincidiu com 0 aparecimento das primeiras obras importantes de direito internacional e que iriam pasmar a doutrina futura. Surgiram também as primeiras decisões judiciárias sôbre cônsules e agentes consulares, as quais iriam servir de base às decisões posteriores, principalmente na Inglaterra e nos Estados Unidos. O fato da instituição consular haver sofrido uma salutar reforma posteriormente, pela :ubstituição dêsses cônsules electi pelos de carreira, não modificou, como deveria, os ensinamentos dos doutrinadores, que ainda hoje se baseiam no que foi escrito anteriormente, sem levar em consideração a posição real e atual da instituição consular.

No século XIX, a instituição sofreu novas transformações, entrando destarte no seu quarto período, a que poderíamos denominar dos cônsules de carreira.

O surto econômico-comurcial, coñn o conseqüente aumento de expuriações e importações, veio exigir dos países uma revisão de seu sistema consular, que não mais podia continuar entregue aos cônsules honorários.

Os movimentos migratórios também vieram acarretar maior trabalho nas repartições consulares, quer dos países de imigração (incumbidos da seleção Jos imigrantes) quer dos de emigração (proteção de nacionais).

As reformas operadas se concretizaram nos regulamentos adotados ou revistos. Os primeiros regulamentos foram, porém, do século XVII, citando-se em primeiro lugar o dos Países Baixos, de 1658, aplicável aos cônsules na Espanha, França e Itália; e uma ordenança francesa, de 1681, que continha alguns dispositivcs sôbre cônsules. Êstes textos eram, contudo, rudimentares e nos dois citados países surgiram modificaçőes fundamentais em 1871 e 1833 .

O Brasil, dada a transplantação da organização burocrática portuguêsa para o Rio de Janeiro em 1808, não se viu obrigado a improvisar, como as demais nações latino-americanas, uma repartição dos negócios exteriores: pcr ocasião da sua emancipação, possuia os elementos necessários, que the iriam dar uma posição ímpar na política externa da América do Sul.

Aliás, mesmo antes de nossa Independência José BonIfácio nomeou ANTÔNIo MANOEL CoRrea da CÂmara cônsul e agente comercial em Buencs Aires, isto em maio de 1822 .

E curicso lembrar que o Govêrno Republicano do Recife, em 1817, nomeou ANTônio Gonçalves DA CRUz cônsul nos Estados Unidos. O mesmo em 15 de janeiro de 1823 era nomeado Cônsul Geral na União Americana.

Desde cedo sentiu-se a necessidade de um regulamento e no Relatório de 1831 se lembrava a necessidade da aprovação pela Assembléia Geral do Projeto de Regulamento. 
O primeiro Regulamento Consular, Decreto $\mathrm{n}^{\circ} 520$, de 11 de junho de 1847, antecedeu ao do Corpo Diplomático. Contràriamente ao que sucede com êste, o do Corpo Consular é bastante explícito e abrange 230 artigos. Trata da nomeação, classes, vencimentcs e prerrogativas dos empregados consulares; do exercício, suspensão e cessação do ofício consular; das relações dos empregados Consulares entre si e com seus superiores; do favor ao comércic; do favor à navegação; dos acidentes, perigos e mais circunstâncias ocorridas na viagem; da proteção aos brasileiros; da Secretaria e Expediente consulares; e de algumas disposiçōes gerais. Foi subscrito por SATURNino DE SousA E OLIVEIRA.

O Regulamento de 1847 foi substituído em 24 de maio de 1872 por outro (Decreto n. ${ }^{\circ} 4.968$ ), que perdurou até o fim do Império. Numerosos foram os Regulamentos c Consolidações baixados durante a República. Atualmente, não há no Brasil uma Carreira Consular independente da Diplomática; existe uma só carreira, a de "Diplomata", cujo estatuto básico é o Decreto-lei n. ${ }^{\circ}$ 9.202, de 26 de abril de 1946. O último Regulamento Consular foi aprovado pelo Decreto n. ${ }^{\circ} 24.113$, de 12 de abril de 1934 ; mas no exercício de suas funções, os cônsules brasileiros recorrem ao "Manual de Serviço", que dispõe minuciosamente sôbre tôdas as atividades consulares.

\section{CÔNSULES E DIPLOMATAS}

Săo inúmeros os autores que têm procurado pôr de relêvo as diferenças existentes entre as carreiras diplomática e consular. Mas se no papel é possível traçar limites claros, ccnstata-se que os mesmos são poucos na prática. Em ambos os casos, trata-se da manutenção dos interêsses nacionais na esfera internacional.

De um modo geral é lícito citar as seguintes diferenças entre ambas as carreiras, diferenças estas que nem sempre são absolutas:

$1^{\circ}{ }^{\circ} \mathrm{O}$ agente diplomático representa o seu Estado perante outro, ao passo que o cônsul só o representa perante as autoridades locais;

$2^{\circ}{ }^{\circ}$ ) o agente diplomático é acreditado por meio de credenciais, o cônsul não é acreditado, mas sim munido de uma carta-patente;

$3 .^{\circ}$ ) o agente diplomático entra plenamente em função mediante a entrega solene de suas credenciais, ao passo que cônsul o faz após a concessão do exequatur;

4..$^{\circ}$ ao terminar a missão do agente diplomático as suas recredenciais são entregues ao Govêrno junto ao qual se achava acreditado, ao cônsul não corresponde um documento equivalente;

$\left.5 .^{\circ}\right)$ as imunidades diplomáticas são ccnsideráveis e absolutas, as consulares são reduzidas e pessoais;

$6^{\circ}$ ) o agente diplomático tem jurisdição sôbre todo o território do país onde exerce a sua função; a jurisdição do cônsul se limita ao respectivo distrito consular (que poderá abranger todo o território de um país); 
7. ${ }^{\circ}$ o agente diplomático só lida com o Ministério das Relações Exteriores, ao passo que o cônsul tem contato direto com as autoridades locais, não podendo, ccntudo, se dirigir diretamente ao Ministério das Relações Exteriores, salvo na hipótese de não existir missão diplomática do respectivo pais;

$8^{\circ}$ ) a origem histórica das funções consulares é distinta da origem histórica da instituição diplomática.

As citadas diferenças são, porém, bastante relativas. Quanto à primeira, por exemplo, ccnstata-se que a maioria dos autores ensina que o diplomata tem caráter representativo, não sucedendo o mesmo com o cônsul. Tal ponto de vista é errado, pois o consul representa o seu Govêrno perante as autoridades locais, ccnforme dispõe o artigo 24 do Regulamento brasileiro para o serviço consular, aprovado pelo decreto 24.113 , de 12 de abril de 1934 , e o Regulamento consular argentino de 1947 (art. 7. ${ }^{\circ}$ ).

A proteção dos nacionais, citada como at-ibuição característica dos cônsules, é exercida principalmente pelos agentes diplomáticos. Os cônsules não têm o direito de formular uma reclamação a favor de nacional, cabe-lhes, tão sòmente, interceder junto às autoridades locais. A ação diplomática é, ao contrário, mais objetiva, pode haver reclamação, por intermédio do Ministério das Relações Exteriores, por eventuais denegações de justiça ou arbitrariedades e teremos o exercício da proteção diplomática, que é vedada aos cônsules. O "Manual de Serviço" brasileiro dispõe no artigo 566 que "cumpre, igualmente, às Missões diplomáticas prestar assistência aç brasileiros residentes ou de passagem no país, auxiliando-os em suas emprêsas e defendendo-lhes os interêsses", não mencionando, no capitulo referente às atividades consulares, obrigação semelhante.

Contrariu sensu, a função tida por excelência do diplomata, a política, não está fora da esfera de ação do cônsul. Aliás, existem consulados políticos e o Consulado Geral da Grâ-Bretanha no Cairo, quando o Egito era vassalo da Turquia, pode ser apontado como exemplo típico. Os Consulados do Brasil em Caiena e Paramaribo, criados durante a guerra, tinham notòriamente, um papel político, visto que na época a França e a Holanda se achavam sob o jugo da Alemanha nazista. Atualmente, temos alguns consulares de fronteira, os chamados privativos, cuja importância política não pode sər desconhecida.

Mas se ao teórico, ao internacionalista doutrinário, seja lícito dizer que as funções diplomáticas e consulares são distintas, tendo em vista algumas diferenças no modo de nomeaçãc, nas relações com o govêrno local etc., as decisões dos estadistas devem ser pautadas pela conveniência, baseada na experiência. Durante muito tempo as carreiras diplomática e consular foram carreiras estanques, por considerarem os governos que a especialização em cada era indispensável e que as transferências do corpo consular ao diplomático eram desaconselháveis, dadas as diferenças existentes. A experiência demonstrou, porém, que, ao contrário, a fusão se impunha e que o tirocínio diplo. mático era indispensável ao cônsul, como a experiência ccnsular o era ao cliplomata. No Brasil, a fusão foi feita em duas etapas. O Decreto número 19.592, de 15 de janeiro de 1931, dando o primeiro passo nesse sentido, fun- 
diu o antigo quadro da Secretaria de Estado ccm os do corpo diplomático e do corpo consular. Não se fêz então a fusão dêsses dois últimos quadros, porque - conforme expos o chanceler Afranio de Mello Franco, na Introdução ao Relatório de 1931 - "julgou prudente deixar ao tempo a depuração prévia dos respectivos elementos antes de unificar-lhes o pessoal". O artigo 22 do citado decreto previa, porém, a transferência de um para o outro serviço.

A fusão definitiva se verificou em 1938, quando fơ baixado o Decretolei n. ${ }^{\circ} 791$, de 14 de outubro, que revogou o Decreto n. ${ }^{\circ} 19.592$, de 1931 . Se antes da fusão alguns cônsules tinham uma mentalidade exageradamente burocrática, notava-se entre os diplomatas um apêgo excessivo às coisas mundanas. A fusão de ambas as carreiras veio eliminar em parte êstes inconvenientes, criando uma nova classe de funcionários dotados da experiência adquirida nos dois ramos do serviço e, que quer trabalhem em repartição diplomática ou consular, adotam a mesma rotina de trabalho. Se bem que persistam algumas diferenças extrínsecas entre as carreiras, estas tendem a sofrer uma diminuição gradual dadas as suas afinidades intrínsecas.

\section{CLASSIFICAÇÃo DOS CÔNSULES}

Não há, a exemplo do que ocorre com os agentes diplomáticos, uma classificação internacional dos funcionários consulares. Assim, a matéria é deixada-à legislação interna dos Estados, que poderá dar livremente aos seus cônsules o título que quiser. Hoje em dia, contudo, já há uma nomenclatura que conta com a aceitação de quase todos os países e constata-se que os cônsules podem ser classificados segundo a remuneração (cônsules de carreira e honorários) e segundo a hierarquia (cônsules gerais, cônsules e vice-cônsules).

Quanto à remuneração, verifica-se que ao lado dos cônsules pròpriamen. te ditos, isto é, daqueles que são nacionais do Estado que representam, são por êle remunerados e não podem exercer outra profissão, existem os chamađos cônsules honorários, geralmente nacionais de país em que servem e para os quais a função consular é secundária, pois são quase sempre comerciantes .

Aos cônsules de carreira se dá ainda as denominações de cônsules missi ou de profissão ao passo qua os segundos são ainda chamados electi, comerciantes ou ad-honorem.

As expressões cônsules missi e electi, apesar de seu aspecto arcaico, ainda hoje contam com aceitação, se bem que os atuais cônsules honorários (electi) não mais sejam eleitos como o eram na Idade Média. No Brasil, o Decretolei n. ${ }^{\circ}$ 4.391, de 18 de junho de 1942, adota a terminologia em questão.

A tendência dos países é no sentido de abolir cs cônsules honorários, mas considerações várias, principalmente a econômica, têm impedido a extinção total dos mesmos. Com efeito, a prática tem mostrado a conveniência de sua abolição. Flavio Guilhén CASTAÑon lembra as seguintes razões contrárias aos cônsules honorárics:

a) o cônsul electi, ocupado com os seus negócios normais, não tem tempo para tratar das funções consulares; 
b) carece de uma instrução adequada para cumprir a contento as suas obrigações;

c) se fôr comerciante não pođerá ser imparcial nos assuntos relacionados com o seu ramo;

d) não dá uma garantia completa de segurança nas suas atribuiçõzs como depositário do Registro Civil, pelo mesmo fato de carecer de ccnhecimentos necessários;

e) pela mesma razão pode incorrer em erros nas suas funções políticas, notariais, administrativas etc.;

f) o cônsul negociante, exposto aos azares do comércio, pode sofrer uma falência, e passar por uma vergonha pessoal que compromete a dignidade do govêrno que representa;

g) geralmente os cônsules missi não vêem com bons olhos os electi, pois os consideram de categoria inferior, o que provoca sérias dificuldades nos lugares onde existe um corpo organizado. (16)

Os Estados, com o intuito de melhorar cada dia mais o seu serviço exterior, condicionam o ingresso na carreira diplomático-consular ao preenchimento de inúmeras condições, dentre as quais figura uma rigorosa seleção intelectual; e, paradoxalmente, a nomeação dos cônsules honorários, é subcrdinada a um número irrisório de conđições. É óbvio que os cônsules electi não podem ter as aptidões necessárias para desempænhar satisfatòriamente as várias funções consulares que hoje lhe incumbem; sem esquecer que um funcionário terá tudo que perder no caso de ser demitido, o honorário pouco sofrerá, no caso de abusar de sua situação.

O Regulamento para o Serviço Consular Honorário do Brasil, aprovado pelo Decreto $\mathrm{n}^{\circ}$. 23.776, de 30 de setembro de 1947, próibe expressamente aos cônsules honorários algumas das principais atribuições consulares. $\mathrm{O}$ citado Regulamento ainda prevê (art. 37) a designação de um funcionário de carreira para iniciar e instruir, devidamente, os servidores honorários nos negócios das Chancelarias.

A abolição dos agentes consulares, porém, não é viável. Embora não possam desempenhar as funções ccnsulares a contento, prestam, por vêzes, reais serviços ao país que os nomeou. Em certas localidades, principalmente portos, é necessário ter uma repartição consular, mas com frequêencia o pouco rendimento e as rendas diminutas não justificam a nomeação de um funcionário de carreira. Aliás, os agentes consulares são geralmente escolhidos dentre pesscras de boa situação local, possuem um amplo círculo de amizade, bem como fortuna pessoal. Tôdas estas qualidades suprirão algumas das inevitáveis falhas que tenham.

IRIZARRY Y PUENTE ensina que a distinção entre cônsules electi e missi "não tem pràticamente nenhuma ccnsequiência jurídica especial, pois não existe em direito internacional nenhuma diferença apreciável, do ponto de vista de

(16) Derecho Consular em Revista de la Universidad de San Carlos (Guatemala), n. ${ }^{\circ}$ II $(1946)$, pp. 282 e 283. 
categoria, das prerrogativas, das imunidades e dos deveres, na situação das duas classes de cônsules". (17)

OPPENHEIM adota igual ponto de vista: "em direito internacional não existe nenhuma diferença na situação geral das duas espécies de cônsules". (18)

Um exame, mesmo superficial, das legislações dos diversos países nos mostra que os citados autores não têm razão. Quanto às atribuições, vimos que os cônsules honorários brasileiros não podem exercer quinze importantes funções consulares. As isenções de impostos aduaneiros dados aos cônsules estrangeiros são quase que invariàvelmente privativas dos missi. O Decretolei 4.391, por exemplo, é explícito, nos artigos 16,27 e 28 , que conferem determinadas isenções aos cônsules de carreira as quais são negadas aos honorários. As normas de precedência, por sua vez, colccam os cônsules electi depois dos missi.

Finalizando, convém fazer mais duas observações sôbre as expressões "cônsules de carreira" e "cônsules honorários".

Embora o título cônsul de carreira seja empregado como sinônimo de cônsul missi, verifica-se que, embora todos os cônsules de carreira sejam missi, nem todos os missi são de carreira. Com efeito, inúmeros países não possuem uma carreira consular, pois, por razões várias, têm o que se chama cónsules de ocasião, nomeados independentemente do preenchimento de determinadas condições e cujo ascenso e aposentadoria não são garantidos. Se a nomeação dos mesmos é fácil e, geralmente, se verifica depois de uma mudança de govêrno, à destituição o é igualmente. No Brasil existem, ao lado dos cônsules de carreira, os cônsules privativos que são cônsules missi, pois percebem gratificação e são brasileiros. Não lhes são aplicáveis, porém, as normas regulamentares em matérias de ajudas de custo, férias extraordinárias, promoçāu, disponibilidade e aposentadoria (Decreto n. ${ }^{\circ} 19.466$, de 6 de dezembro de 1930, art. $30^{\circ}$ ).

Em alguns países, quando um funcionário subalterno desempenha durante vários anos as suas funções a contento, se the confere o título de cônsul ou vice-cônsul honorário. Nesse caso, o funcionário premiado não poderá ser assimilado aos demais cônsules honorários, pois recebe remuneração. O Brasil tem adotado esta prática, que tem a vantagem de deixar a repartição entregue a um funcionáric com a designação de cônsul, nos impedimentos do titular.

Quanto à classificação dos cônsules segundo a hierarquia, são adotadas as seguintes denominações: Cônsul Geral, Cônsul e Vice-Cônsul, além de outras de menor aceitação. Os títulos em questão se aplicam tanto aos cônsules missi quanto aos electi. A doutrina vem propugnando pela não utilização dos mesmos com relação aos segundos, a fim de evitar as habituais divergências entre os dois ramos do serviço consular. A França e a Itália reservam as denominações de cônsul geral, cônsul e vice-cônsul para os funcicnários de carreira e utilizam o título de agente consular para os honorários.

(17) Op. cit. pp. 24 e 25 .

(18) International Law, $8 .^{a}$ edição (Londres - 1955), revista por H. LAUTERPACHT. \$ 420, p. 832 . 
Na organização consular brasileira, encontramos três tipos de cônsules, cada qual com a sua hierarquia própria: os consules de carreira, os privativos e os honorários.

Os cônsules de carreira são, de acôrdo com a orientação geral adotada para os funcionários públicos brasiieiros, de quatro classes: $\mathrm{K}, \mathrm{L}, \mathrm{M}$, e $\mathrm{N}$. A função de Cônsul Geral só é exercida pelos funcionários de classe N. O. título de Cônsul é dado no exterior aos funcionários das classes $L$ e $M$, quando na direção de um consulado, sendo que os da classe $\mathrm{K}$ são denominados ViceCônsules, quer trabalhem em Consulado Geral ou Consulado. Os funcionários das classes $L$ e $\mathbf{M}$ lotados em Consulados Gerais têm a designação de Cônsules Adjuntos e como tais são os substitutos eventuais do titular. O Cônsules Adjuntos, porém, deverão usar, para fins representativos, de relações com as autoridades locais e sociais, a simples intitulação do Cônsul do Brasil.

$\mathrm{Na}$ crganização brasileira as funções dos cônsules gerais são idênticas às dos cônsules, não existindo a subordinação dêstes àqueles, como sucede em outros países. A diferença é que são funcionários mais graduados, incumbidos da direção de uma chancelaria de maior movimento.

Os cônsules privativos são de uma só classe. Geralmente, existem nos consulados privativos vice-cônsules honorários, que poderão ser, eventualmente, encarregados de sua direção.

Os consulados honorários são dirigidos pelo Cônsul Honorário que, nos impedimentos, será substituído pelo Vice-Cônsul Honorário. Quanto aos viceconsulados, a direção cabe a um Vice-Cônsul honorário que terá como substituto um agente consular.

$\mathrm{Na}$ organização brasileira não existem cônsules gerais honorários, título pomposo utilizado por alguns países de escassa população e extensão territorial. Com efeito, constatado um aumento considerável de renda e de serviço de um consulado honorário, a medida a ser tomada é transformá-lo em de carreira. No tocante aos cônsules gerais honorários, verifica-se que o título não tem relação com as funções e que o mesmo invariàvelmente é o único funcionário do consulado geral.

\section{SELEÇÃo DE CÔNSULES}

A importância das funções dos cônsules faz com que os governos procurem aperfeiçoar cs métodos de sua seleção. Conforme vimos, os quadros consulares podem ser constituídos de três tipos de funcionários: os de carrei$\mathrm{ra}$, os de ocasiāo (que sem ser de carreira são funcionários pagos e da nacionalidade do Estado que os nomeia), e os honorários. Só os primeiros é que estão sujeitos a uma seleção rigorosa; sendo que os demais são nomeados mediante o preenchimento de algumas poucas qualidades, cuja apreciação fica a cargo daquele que faz a nomeação.

Já no tocante aos cônsules de carreira, a tendência é no sentido de se exigir determinadas condiçōes, cuja constatação pode ser feita de modo objetivo, o que não sucede com as qualidades. As condições que são geralmente exigidas são: determinado grau de instruçāo, nacionalidade do país sexo masculino, saúde e idade. Há tempos apresentamos trabalho no qual foram exa- 
minadas ,em linhas gerais, as condições exigidas, em que consistem e o sistema de seleção vigente no Brasil, razão porque não serão repetidos os conceitos então expendidos. (19)

\section{NOMEAÇÃO PARA SERVIR NO EXTERIOR}

O direito internacional não estabelece regras sôbre 0 modo de nomeação dos cônsules. Nessas condições, cabe à legislação interna de cada Estado fixar as normas a respeito. A Convenção de Havana assim se manifesta: "Art. $2 .^{\circ}$. A forma e requisitos para serem nomeados... seräo regulados pelo direito interno de cada Estado".

Não basta contudo que a nomeação seja feita de acôrdo com a legislação do Estado que o nomeia, é necessário ainda o preenchimento de algumas condiçốes fixadas pelo que o aceita. Embora não haja uniformidade a respeito, a prática tende a igualar as normas adotadas.

$\mathrm{Na}$ maioria dos países, a nomeação dos cônsules é atribuição exclusiva do Poder Executivo. E o que sucede na Argentina (Regulamento de 7 de maio de 1947), Bolívia, Chile, Guatemala, Uruguai e Venezuela. Em outros, como nos Estados Unidos, Cuba e Peru, a nomeação é da alçada do Chefe de Estado mas a mesma se acha condicionada à aprovação do Senado.

Quanto ao Brasil, a nomeação é sempre da alçada do Executivo, mas ela nãc é feita sempre da mesma maneira, dependendo da qualidade do cônsul, se de carreira, privativo ou honorário.

Os cônsules de carreira e os privativos isto é, os cônsules missi, são nomeados mediante Decreto firmado pelo Presidente da República e referendado pelo Ministro das Relações Exteriores. A nomeação de ocupantes de funções honorárias será feita por decretc, quando se tratar de Cônsules honorários, e, por portaria, quando se tratar de vice-cônsules honorários ou de Agentes consulares (Decreto n. ${ }^{\circ} 23.776$, de 30 de setembro de 1947, art. 18).

A nomeação por decreto é, porém, de efeito interno e administrativo. Do ponto de vista do direito internacional a nomeaçăo decorre da Carta-patente, que "é o documento firmado pelo Chefe de um Estado, no qual constam: o nome, o título e as atribuições de um funcionário consular e que é remetido ao Govêrno estrangeiro para que conceda o exequatur."

Uma vez firmada pelo Chefe de Estado e referendada pelo Ministro das Relações Exteriores, a Carta Patente é remetida à missão diplomática no país onde o Cônsul servirá a fim de encaminhar à repartição competente para a sua aprovação, que é feita pela concessão do exequatur. $\mathrm{O}$ exequatur é o ato pelo qual o Govêrno do Estado onde o cônsul vai desempenhar as suas funções o aceita como tal, permitindo que entre no exercício das mesmas.

O exequatur pode ser recusado ou poderá subordinar o exercício das atribuições consulares a determinadas obrigações.

A qualidade oficial do cônsul só é reconhecida pelas autoridades locais depois da concessão do exequatur, mas isto não significa que antes $\sigma$ cônsul

(19) G.E. Do NAscimento E Silva: Seleção de Cônsules e Diplomatas, em Revista do Serviço Público, ano XIV, vol. II - N. ${ }^{\circ} 3$, de julho de 1951, pp. 5 e seguintes. 
não possa assumir a direção da repartição e se ocupar dos assuntos de caráter interno, como o despacho de navios, legalização de documentos etc. justificase o exercício dessas funçōes antes do exequatur, dada a demora com que o mesmo é concedido em alguns países. A Convenção de Havana (art. 6. ${ }^{\circ}$ ) prevê a concessão de um reconhecimento provisório, até que seja dado o exequatur de estilo.

O pedido de exequatur é feito por via diplomática, não podendo ser feito pelo cônsul ou o seu antecessor.

O exequatur é concedido no Brasil em forma de um documento especial, firmado pelo Presidente da República e referendado pelo Ministro das Relacỗes Exteriores. Em outros, como a Argentina, se escreve na própria carta patente a palavra "acéptase", a qual é subscrita pelo Chefe de Estado e referendada pelo Chanceler.

Uma vez concedido $\sigma$ exequatur, pode êle ser cassado, mas geralmente os Estados evitam chegar a êsse extremo, pedindo antes a retirada do funcionário. Em caso de guerra, porém, o exequatur é cassado.

Quando o cônsul é nacional do país, as exigências são em maior número. Antes de mais nada, constata-se que $\sigma$ Brasil não dá autorização aos seus funcionários públicos para aceitar o título de cônsul de outro país. No caso do interessado não ser funcionário público, deverá requerer ao Govêrno da República a necessária licença para aceitar e exercer o lugar de agente ccnsular estrangeiro, sob pena de perder, nos termos do art. $130, \mathrm{n}^{\circ}$ II da Constituição, a sua nacionalidade brasileira. O requerimento é dirigido ao Presidente da República, por intermédio do Ministro da Justiça e Negócios Interiores. Expedido o respectivo decreto de licença, é êle remetido pelo Ministério da Justiça ao das Relações Exteriores onde ficará à disposição do interessado. Só depois da expedição do decreto de licença é que se concede o exequatur (Decreto-lei $n .^{\circ} 4391$, de 18 de junho de 1942 , art. $9 .^{\circ}$ ).

Assim que um funcionário consular brasileiro chega ao seu novo pôsto, comunica à Secretaria de Estado das Relaçōes Exteriores que assumic a direção do Consulado. Antes de tomar essa medida, deverá tomar outras de natureza burocrática, como verificar o estoque de estampilhas consulares, ver se o valor do depósito da renda consular em banco corresponde ao dos emolumentos registrados no "Diário de Emolumentos" e ainda ao das estampilhas que, conforme a escrituração feita no "Diário de Estampilhas", tiverem sido utilizadas durante o mês; se as contas dos adiamentos das verbas de "Aluguel de Casa" (ou de "conservação do prédio") e de "Expediente" estão corretas; se os papéis e móveis existentes conferem com o último inventário; e se é exato o estoque de passaportes. Se tudo estiver em ordem será lavrado no "Livro de Inventários e entrega do Arquivo" a competente declaraçăo de entrega do Arquivo.

O novo titular deverá também comunicar à Delegacia do Tesouro Brasileiro em Nova York, além de a Secretaria de Estado, que assumiu a direção do Consulado. Deve ainda tornar público pelo meio que julgar mais conve- 
niente o fato de ter entrado no exercício de suas funções, para que os brasileiros residentes em sua jurisdição ou de passagem o reconheçam como tal e a êle se possam dirigir. (20)

\section{CORPO CONSULAR NACIONAL E ESTRANGEIRO}

A expressão corpo consular é empregada em dois sentidos: pode englobar todos os funcionários consulares de um determinado país seja onde estejam, ou abrangerá os cônsules de distintas nacionalidades residentes em determinada cidade. No primeiro caso temos o corpo consular nacicnal e no segundo o corpo consular estrangeiro.

Quanto ao corpo consular nacional, basta dizer que êle ccmpreende não só os funcionários de carreira senão também os honorários.

Por sua vez, a expressão corpo consular estrangeiro púde ser empregada com duas acepções distintas: ou abrange sòmente os chefes das repartições consulares ou se estenderá ainda aos vice-cônsules e demais məmbros constantes da lista do corpo consular.

Flavio Guilllén Castañon ensina que o corpo consular estrangeiro é "constituído pela reunião de todos os cônsules radicados numa mesma localidade e tem por objeto a união de seus membros, assim como o seu agrupamento protocolar para assistir às cerimônias oficiais e às recepções públicas". (21)

O corpo consular não tem personalidade jurídica própria, e, portanto, não goza de direitos próprios nem tem deveres.

Em algumas cidades, principalmente nas capitais, o corpo consular só existe nominalmente, mas em outras tem uma vida real, possui uma diretoria, regulamento e fundo social.

O corpo consular tem finalidades protocolares eminentes a sua existência e que independem de um regulamento. Além dessas finalidades outras poc̉erão ser criadas pelo próprio corpo que as consolidará no seu Regulamento.

O corpo consular costuma se reunir a fim de tomar decisões sôbre assuntos que lhe são inerentes como eleição da diretoria, exame e aprovação das contas do tescureiro etc. A não ser no tocante aos assuntos que dizem respeito exclusivamente ao corpo consular como um conjunto, as decisões devem ser tomadas por unanimidade. Em outras palavras, o corpo ccnsular poderá se reunir com o intuito de uniformizar o modo de proceder individual de seus membros em determinada questão ou cerimônia e nesse caso o voto da maioria não obriga a um membro, que poderá, livremente, agir em sentido distinto; tratando-se de uma reforma de estatutos, eleição de diretório ou decisão análoga, a unanimidade não é exigida.

Nas votações efetuadas, corresponde um só voto a cada Estado representado, cabendo ao representante de maior hierarquia lançá-lo. A ordem de votação será estabelecida pela procedência ou por ordem alfabética.

\footnotetext{
(20) José ANgelo de CASTro, Início das Funçôes Consulares no Exterior, FFunchal, 1948.

(21) Op. cit., pp. 285 e 286.
} 
Da mesma maneira que um Cônsul não deve fazer reclamações perante as autoridades locais, cabendo-lhe fazer simplesmente solicitaçóes, o corpo consular deverá se abster de fazer protestos ou reclamações.

Não existe uma norma geral sôbre a precedência dos cônsules. De um modo geral, pode-se adotar as seguintes regras, que contam com razó́vel aceitação: havendo cônsules electi e cônsules missi, os segundos gozarão invariàvelmente de precedência, obedecendo-se quanto a êles a que leva em consideração a categoria (cônsules gerais, cônsules e vice-cônsules) e, dentro de cada classe a ordem de antiguidade do exequatur. Quanto aos cônsules honorários, só se deve atender à data da concessão do exequatur, pouco importando o título que pcssuam, seja de cônsul geral, cônsul, vice-cônsul ou agente consular.

O corpo consular é presidido por um Decano e êste será normalmente o cônsul geral de carreira de mais antigo exequatur. Mas da mesma maneira que não existe uma regra geral sôbre a precedência consular, não há uma relativa ao decanato. Nas cidades em que não existem cônsules gerais de carreira, por exemplo, outra regra terá que ser adotada.

\section{AS FUNÇÕES E ATRIBUIÇÕES CONSULARES}

As atribuições consulares variam não só de país para país senão também no tempo.

No estudo da evolução da instituição consular tivemos ensejo de notar que as funções dos cônsules na antiguidade e na Idade Média eram bem diversas das de hoje. Ao passc que então a função primordial era a de juiz, exerciam os cônsules outras de caráter político e cutras consulares pròpriamente ditas. J. IRIZARRY y PUENTE em interessante e importantíssimo trabalho, (22) nos mostra que diversas eram as funções e os poderes dos cônsules na Idade Média. O citado autor as classifica em duas categorias, as de agente político e as de agente comercial. Como agente político tinha audiência direta com o soberano local, exercia a representação diplomática, protegia os interêsses nacionais e negociava tratados. As funções que caem sob a rubrica agente comercial eram mais extensas, sendo os seus poderes de caráter executivo, legislativo e judiciário.

Com a formação dos grandes Estados, os cônsules perderam as titribuições judiciárias e as diplomáticas. A redução das funções provocou uma fase de decadência na instituição, mas com os surtos comercial e industrial do século XIX e XX duplicaram-se consideràvelmente as atribuições ccnsulares . Não cabe aqui examinar as mesmas detalhadamente, o que será feito oportunamente em trabalho específico sôbre a questão. Limitar-nos-emos, portanto, a uma enumeração classificada das citadas funçōes e atribuiçōes.

Os deveres e as atribuições do cônsul resultam das legislações internas do Estado que o nomeia e da do que o admite, de tratados e convençóes e do costume internacional.

(22) Functions and Powers of the Foreign Consulate. A Study in Medieval Legat History, New York, 1944. 
Inicialmente constatamos que o cônsul tem deveres para com o seu Estado e para com o de residência. Quanto a êstes, é óbvio que o cônsul, como o diplomata, deve evitar tôda ofensa ao país de residência, seus dirigentes, suas instituições e suas leis.

No tocante às funções e atribuições dos cônsules para com o seu próprio país, constata-se que os autores são mais ou menos unânimes na sua enumeração, mas discordam quanto à classificação.

HILDEBRANDO Accioly as coloca em três categorias: funções de cbservação, funções de proteção e funções executivas (funções de natureza pròpriamente administrativa, funções notariais e funções de oficial do registro civil). Lembra ainda que além das citadas atribuições de caráter geral, pode a legislação interna de cade país determinar outras, de caráter particular. (23)

Preferimos fazer uma enumeração mais analítica, citando as seguintes classes que freqüentemente se confundem: proteção e tutela dos nacionais, serviço militar, deveres relativos à navegação, econômicas e comerciais, políticas e culturais, aduaneiras e arrecadadoras, judiciárias notariais e de oficial de registro civil, administrativas, de propaganda e outras de somenos importância. (24).

\section{PRERROGATIVAS E IMUNIDADES CONSULARES}

O direito internacicnal moderno reconhece que os Cônsules necessitam para o bom desempenho de suas funçốes um mínimo de prerrogativas e imunidades, tendentes a colocá-los fora da jurisdição do país de residência.

Aos cônsules estrangeiros de carreira se reconhece, com algumas restrições, os seguintes privilégios: inviolabilidade pessoal, imunidade de jurisdição civil e penal, não obrigatoriedade de comparecer em juízo como testemunha $\mathrm{e}$ isenção de determinados impostos.

A inviolabilidade se justifica pela necessidade de thes assegurar o livre exercício de suas atividades. de exercê-las. $O$ argumento apresentado por uns de que o consulado não se limita ao cônsul, mas é integrado por outros funcionários, como o vice-cônsul e os chanceleres, não subsiste, pois determinados documentos só podem ser firmados pelo titular. Além do mais, a prisão de um cônsul sempre implicará num acinte ao Estado que o nomeou. A nosso ver, no caso de um cônsul de carreira cometer um crime de certa gravidade, o Estado de residência deverá solicitar do Estado que o nomeou autorização para o julgar e punir. Na hipótese dêste último, aquiescer, $\sigma$ funcionário deverá ser destituído de sua qualidade de cônsul, mediante a cassação do exequatur, e será iniciado o competente processo. No caso contrário, o único recurso que restará ao Estado de residência será ou pedir a sua retirada ou então cassar pura e simplesmente o seu exequatur.

Seja como fôr, são poucos os autores que equiparam a inviolabilidade consular à diplomática, isto é, a consideram absoluta. Igualmente, são raros

(23) Op. cit. pp. 396-401.

(24) G.E. do Nascimento E Srlva: Manual de Derecho Consular, p .112. 
aquêles que, baseados nos autores antigos, colocam os cônsules em pé de igualdade com os demais estrangeiros, sujeitando-os a possíveis prisốes. Geralmente, os internacionalistas, como as Convenções consulares, reconhecem a inviolabilidade consular com ressalvas, consubstanciada na expressão "salvo no caso de crime inafiançável", ou outro parecido, como "salvo caso de crime" ou "crimes graves ou atrozes". E esta a orientação da Convenção de Havana sôbre funcionários consulares, cujo art. 14 dispõe"... os agentes consulares nacionais do Estado que os nomeia não poderão ser detidos, nem processados, senão nos casos de serem acusados de algum fato qualificado de delito pela legislação local".

A inviolabilidade consular só pode ser absoluta, qualquer exceção à mesma, traduzida em fórmulas vagas, é um título em branco para o juiz local, que poderá até condenar um cônsul pelo fato de enviar um relatório político ou econômico, sob o pretexto de que se dedica à espionagem.

A imunidade de jurisdição reconhecida aos cônsules sofre, igualmente, tantas e tamanhas restrições que acabam anulando-a. Aqui, também, nota-se maior liberalidade entre uns que entre outros. De um modo geral, a regra é a da isenção jurisdicional, mas a mesma se acha condicionada aos atos praticados no exercício de suas atribuições ou funções. Outros falam no caráter consular ou na qualidade oficial.

A Convenção de Havana, por exemplo, é clara a respeito, regulando, no artigo 16: "Os Cônsules não estão sujeitos à jurisdição local pelos atos executados com caráter oficial, nos limites da sua competência. No caso em que um particular se ccnsidere prejudicado pela ação do cônsul, êle apresentará a sua reclamação perante o Govêrno, o qual, se a considerar procedente, a fará valer pela via diplomática".

A necessidade de não estorvar o cônsul no exercício de seus deveres justifica o seu não comparecimento como testemunha em processos que não o interessem diretamente. Daí a regra de que o seu depoimento será tomado na chancelaria e com tôda a consideração, a não ser que êle se prontifique a comparecer em juízo para prestá-lo. Em matéria penal, contudo, se tem admitido o comparecimento do cônsul. Nessa hipótese, não deverá ser citado, mas sim convidado por meio de carta escrita em têrmos corteses, carta na qual, de preferência, se the permitirá marcar o dia e a hora que mais the convier.

A Convenção de Havana se ocupa dessa prerrogativa no seu artigo 15 em redação que poderia ter sido mais feliz. "Nas causas criminais, poderá pedir-se, pela acusação ou a defesa, a assistência em juízo, como testemurihas, dos agentes consulares. Essse pedido se fará com tôda a consideração possivel à dignidade consular e aos deveres do cargc, e será cumprido por parte do funcionário consular. Nos assuntos civeis os agentes consulares estarão sujeitos à jurisdição dos tribunais, com a limitação, todavia, de que, quando o cônsul for nacional do seu Estado e não se dedicar a nenhum negócio privado com fins de lucro, a sua declaração lhe será tomada, verbalmente ou por escrito, na sua residência ou escritório e com a devida consideração. O Cônsul poderá, contudo, voluntàriamente, prestar declaraçōes como testemunha, 
quando isso não the ocasione sérios transtornos no desempenho dos seus ieveres oficiais".

Temos por fim a imunidade de jurisdição fiscal. Gozam os cônsules de carreira, sob condições de reciprocidade, de algumas isenções de impostcs. A matéria é bastante confusa, mas de um modo geral verifica-se que ela abrange os impostos pessoais diretos como o impôsto de renda, e os que incidam sôbre os seus bens móveis. Não gozam, pelo comum, de isenção alfandegária, mas os móveis e objetos destinados à primeira instalação não pagam os impostes aduaneiros. Quanto às entradas subseqüentes, a legislação de alguns países reconhece, sob condição de reciprocidade, semelhante privilégio, como a lei n. ${ }^{\circ} 4640$ (de 19 de outubro de 1929) do Chile e a lei sôbre tarifa alfandegária da Holanda. Os Estados Unidos, também, são favoráveis a esta norma.

Quanto ao impôsto de renda, a isenção se impõe, pois do contrário haveria uma dupla taxação, já que os cônsules pagam o mesmo ao respectivo país. E lógico que a isenção só se aplica aos vencimentos oficiais e não a possíveis lucros auferidos em atos de comércio no país de residência (aliás, a legislação de quase todos os países veda aos funcionários de carreira o exercício de atos de comércio). No México, no Equador, em Honduras e no Salvador, a legislação prevê expressamente que os cônsules honorários pagarão os impostos como os demais estrangeiros domiciliados ou residentes no seu território.

Também, os artigos de expediente do consulado, bem como os móveis bandeiras, escudos, uniformes, produtos para mostruário, carimbos etc... não pagam direitos aduaneiros. Este privilégio, contudo, é inerente ao consulado, e não pode ser considerado um privilégio pessoal do cônsul.

No Brasil, o decreto-lei n. $0^{\circ} 4.391$, de 18 de junho de 1942, dispóe no artigo 16 que o "Govêrno brasileiro s óconcede isenção de direitos aduaneiros para o primeiro estabelecimento dos Agentes consulares e demais funcionários de carreira do Serviço Consular dos países que, não havendo firmado convenções ou acôrdos especiais com o Brasil e desde que os mesmos Agentes consulares e funcionários sejam efetivamente de carreira e nacionais do Estado que os nomeou e não exerçam nenhuma outra atividade com o propósito de lucro e desde que não se tratem de artigos cuja importação seja proibida pelas leis brasileiras. $\S 10^{\circ}$ Concede também isenção de direitos para os artigos de expediente importados pelos Consulados dos países que do mesmo modo procedam para com os Consulados brasileiros".

O mesmo decreto-lei prevê ainda (art. 27) que as municipalidades brasileiras concederão, scb reciprocidade, isenção de taxas de circulação para os automóveis pertencentes aos funcionários de carreira; mas frisa que os cônsules honorários não gozarão de semelhante franquia.

A Convenção de Havana, por sua vez, trata da imunidade fiscal nos seguintes têrmos: "Tanto os agentes consulares, quanto os empregados de um consulado, nacionais de um Estado que os nomeie, que não se dediquem a negócios, com fins de lucro, no Estado onde desempenhem as suas funções, estão isentos de tôda contribuição nacional do Estado, da prevíncia ou do município, imposta à sua pessoa ou bens, exceto da que recaia sôbre a posse ou propriedade de bens imóveis situados no Estado em que exerça as suas 
funções ou sôbre os prcdutos dos mesmos. Os agentes consulares e empregados nacionais do Estado que representem estão isentos de impostos sóbre os ordenados, honorários ou diárias recebidas por êles em retribuição ilos seus serviçcs consulares".

Afćra as franquias expressamente previstas nas Convenções e na legislação interna, os cônsules pagarão os demais impostos, como os indiretos (o de consumo, por exemplo), os imobiliários e os referentes a negócios particulares, em que o cônsul possa cstar eventualmente metido.

\section{TÊRMO DA FUNÇÃO CONSULAR}

As funções de cônsul missi terminam normalmente pela sua transferência para outro pôsto ou então para a Secretaria de Estado das Relações Exteriores. Quanto aos cônsules honorários finalizam a mais das vêzes pelo falecimento do titular.

Essa questão, como quase tôdas as de direito consular, não tem merecido a devida atenção dos autores, que se limitam a transcrever o que foi dito anteriormente. EpITácio PessoA, no seu Projeto de Código de Direito Internacional Público (art. 178), diz que as funções do cônsul cessam :

a) pelo seu falecimento;

b) pela sua aposentadoria, remoção, demissão ou declaração em disponibilidade;

c) pela cassação do exequatur.

O citado artigo foi acolhido ipsis literis pelo Projeto sôbre Cônsules adotado, em 1927, pela Comissão Internacional de Jurisconsultos Americanos (art. 26) e pela Convenção sôbre agentes consulares de Havana (art. 23), que suprimiu apenas a referência à "declaraçãc em disponibilidade".

A enumeração não satisfaz e parece-nos preferível dizer que as funções do cônsul missi podem findar por ação do Estado que o designa, por ação do que o aceita ou poderá resultar de causas intrínsecas ao funcionário.

Quanto à primeira hipótese - ação do Estado que o designa, temos a remoção ou transferência, a aposentadoria prematura, a declaração em disponibilidade, a demissão ou, excepcionalmente, uma alteração bastante no Estado ou no Govêrno.

Finalizará a missão consular em virtude de ação do Estado que o aceita pela expulsão, pedido de retirada e cassação imediata do exequatur. No caso do Estado ou Govêrno sofrer uma transformação transcendental, poderá haver também o fim das funçōes.

Por fim, as funções poderão terminar por causas intrínsecas ao próprio funcionário, como licença, demissão ou aposentadoria a pedido, abandono, aposentadoria automática, invalidez ou falecimento.

Alguns autores ainda ensinam que a missão pcderá terminar por ação de ambos os Estados e, exemplificando, dão as seguintes hipóteses: rompimento de relações ou guerra. Data venia, discordamos nesse particular. Com efeito, em ambas as hipóteses não há um ato bilateral da qual resulta a terminação das funções consulares dos representantes dcs dois Estados; mas sim cada 
Estado, unilateralmente, cassa o exequatur dos cônsules do outro. Embora autores de nomeada, como Clovis Bevilaqua, Lafayetre R. Pereira, F. DESPAGNET e I. IRIZARRY Y PUENTE (25) citem a guerra entre os modos pelos quais finda a missão consular, julgamos preferível adotar a doutrina contrária, acolhida tàcitamente, por exclusão, pela Convenção de Havana, por Epitácio Pessoa, P. Fauchille e Antero. (26) Êste último assim se exprime: "A guerra não põe necessàriamente fim às funções consulares, visto que elas representam um caráter pacífico, e podem, por isso, coexistir com o Estado de beligerância. Todavia, de fato, e regra geral, as missões consulares acabam pela guerra e os consulados são confiados a uma nação amiga".

A prova de que a guerra não põe têrmo automàticamente às funções do. cônsul está na prática dos Estados que, depois de haverem declarado a guerra, cassam, por um ato distinto, os exequatur dos cônsules do outro país; sendo. que entre a declaração de guerra e a cassação dos exequatur pode haver um período mais ou menos extenso. O Brasil, por exemplo, em 11 de abril de1917 declarava sem efeito os exequatur concedidos a todos os funcionários consulares do Império alemão no Brasil (Dec. 12.441). Em 28 de janeiro. de 1942 adotava igual procedimento com relação aos cônsules da Alemanha nazista.

No caso de guerra seguida de cassação de exequatur, os Estados costumam entregar a proteção dos cônsules de uma nação amiga os interêsses até então confiadcs aos seus próprios funcionários.

Quanto à ruptura de relações, constata-se, igualmente, que a função só termina havendo a revocação do exequatur. Quando ocorre simplesmente a ruptura de relações diplomáticas, ela não atinge às funções consulares.

As modificações bruscas no regimen político de um país também não afetam, de imediatc, a situação de seus cônsules no exterior, nem implicam na exigência de novo exequatur para os estrangeiros residentes no país. Nada obsta, contudo, que, como conseqüência de uma revoluçăo ou mudança política violenta, sejam afastados os cônsules, como os diplomatas, que não merecem a confiança do novo regimen.

Se, porém, o território onde se acha instalada a repartição consular passar a pertencer a outro Estado ou se emancipar, será necessário cutro exequatur.

A função consular terminará também pela extinção do Estado que nomeia ou pela do Estado que aceita.

Quando um cônsul é transferido ou é chamado de volta ao respectivo país, a missão diplomática não é obrigada a comunicar tal fato ao Govêrno do país, pois êsse tomará conhecimento da mudança do cônsul quando fôr solicitado exequatur para o novo titular. O Cônsul removido deverá, contudo, despedir-se das autoridades de sua jurisdição, por meio de visitas ou comunicações.

(25) Op. cit., vol. $10^{\circ}$,p. 413; Principios de Direito Internacional vol. $10^{\circ}$ (Rio de Janeiro - 1902), p. 464; Cours de Droit International Public (Paris - 1910), p. 537; op. cit., p. 478 .

(26) Projeto de Códigóo de Direito Internacional Público ,Rio de Janeiro, 1911, 8rt. 178; op. cit. p. 140; O Direito Internacional (1932), p. 292. 